\title{
More Guns Without Less Butter: Improving Australian Defence Efficiency
}

\author{
Henry Ergas and Mark Thomson ${ }^{1}$
}

\begin{abstract}
Defence outlays amount to 1.8 per cent of Australia's GDP. Nonetheless, the processes by which those amounts are allocated, and the efficiency with which they are used, have received very little attention outside of the defence sector itself. This paper identifies the major issues involved in securing efficiency in defence expenditure and surveys efforts to ensure that the Australian defence establishment makes good use of public resources. Recommendations are made regarding the operation of the Department of Defence and the scrutiny of crucial defence decisions.
\end{abstract}

\section{Introduction}

Military service can teach you a lot. A little over 20 years ago, one of the authors of this paper was taught how to replace a flat battery in an army diving watch. The technique involved placing the watch on an anvil and hitting it with a hammer. This seemingly counterintuitive approach arose because irreparable watches were replaced gratis from a central store, whereas new batteries had to be purchased locally from limited unit funds. Unintended consequences such as this are only one of the many impediments to defence efficiency.

This paper explores Australian defence efficiency and the prospects for its improvement. While there is an extensive literature in Australia on the strategic issues associated with national defence, little has been written on the economic and financial aspects of defence decisions. This both reflects and perpetuates a lack of serious scrutiny of resource allocation to and in defence. This article seeks to explain these issues to a non-specialist audience and propose remedies.

There is much at stake. The Department of Defence (Defence) currently spends around $\$ 26.5$ billion a year - equivalent to 1.8 per cent of GDP — and directly

1 University of Wollongong, hergas@uow.edu.au; Australian Strategic Policy Institute. 
or indirectly employs close to 1 per cent of the Australian labour force. The immodest goal of this massive diversion of human and financial resources is to be able to defend Australia from attack.

Given the high cost and potentially grave consequences of failure, there are strong incentives to make our defence effort as efficient as possible. Quite apart from the substantial opportunity cost, greater efficiency allows stronger defence within a given budget.

The paper first surveys some economics of defence and recounts past attempts by Australian governments to improve defence efficiency. It then examines current arrangements within Defence from an economic perspective, taking account of recently announced reforms. We conclude with four recommendations.

\section{Economics of Defence}

Defence is a public good. Once provided, additional individuals can consume it without diminishing the amount available to others and, in practice, no individual can be excluded from its benefits. Thus, defence is manifestly non-marketable and it therefore falls to national governments to deliver. Consequently, the usual market imperative which ensures that products are produced at minimum cost (production efficiency) and in the quantities and type desired relative to alternatives (efficiency in the product mix) is lacking. Instead, what is produced and how is determined by one group of people - the government and the military — spending other people's money.

Reflecting this fact, defence efficiency is hampered by widespread principalagent problems. Those problems arise when one party (the agent) undertakes a task on behalf of another (the principal) and two conditions are met: first, the principal and the agent have different preferences (or more generally, differing valuations of outcomes) and, second, the principal cannot costlessly monitor the agent's characteristics or performance.

Principal-agent problems expose the principal to the risks of 'adverse selection' and 'moral hazard'. Adverse selection arises when the principal cannot confidently select the most productive agent nor pay them accordingly. Moral hazard occurs when incomplete monitoring allows agents to pursue their own outcomes at the expense of the principal. As these problems will be anticipated by the parties, or at least encountered by them in the course of their interaction, they give rise to ways of structuring and implementing relationships which cannot fully secure the potential gains from trade. 
While principal-agent problems are not unique to defence, they are especially acute therein because performance is hard to define, let alone monitor. Not only does defence entail highly specialised knowledge, but - in peacetime at least - it lacks the sort of tangible public feedback available in areas such as health and education. To make matters worse, to the extent that performance can be and is measured, the results are all too often withheld from the parliament and public (and sometimes even the government — see Smith and Clare (2010)). Even more critically, defence capability is frustratingly hard to measure; it only has utility relative to that held by countries we might go to war against, and then only in the context of dimly foreseeable contingencies with difficult-toestimate likelihoods, consequences and outcomes.

To complicate matters further, the competing agenda of entities within a defence organization (not least the individual services) means there is little alignment of interests and incentives. Even when this multiplicity of agents does give rise to competition, that competition may well be inefficient, for instance, as each unit imposes unnecessary costs on others. And no less often, it may instead give rise to collusion at the expense of the principal.

Pervasive principal-agent problems coupled with the absence of market dynamics in defence (1) compromise efficiency in the product mix, and (2) hamper production efficiency. The former arises in the selection of military capabilities for the defence force. While the outcome sought - defence of the nation - is relatively clear, the military force best suited for that purpose is as much a matter of judgement as analysis. One risk is that strategic imperatives will be ignored because of institutional inertia or subordinated to narrow professional military aspirations. ${ }^{2}$

Production efficiency - minimising the cost of outputs - is eroded in several ways. To begin with, governments themselves often pursue inefficient options to satisfy political imperatives - especially regarding the location of facilities and the sourcing of defence materiel. Naval shipbuilding, for example, has been and still is being undertaken in Australia even when doing so involves Effective Rates of Assistance well in excess of 100 per cent, which hardly seems consistent with the public interest (Pappas 2009: Chapter 14).

No less problematic than the relationship between the community (as the principal) and government (as its agent) is that between the government (as the principal) and its defence organization (as the agent). Absent effective oversight of performance, defence organizations have few reasons to strive for higher

2 History is replete with examples of military technologies, such as cavalry and battleships, which were retained long after obsolescence at the insistence of the military. See, for example, Weinberg (2009). A good exploration of how single-service mindsets can unprofitably skew decisions about the structure of armed forces is Builder (1989). 
productivity (at least in peacetime). Rather, they face many temptations to do the opposite. Apart from the natural tendency to build and multiply bureaucratic fiefdoms - over the past 12 years the number of deputy-secretary and military equivalents in Australia's defence hierarchy has more than doubled - it is almost always easier to have more people doing a job than fewer, and likewise easier to tolerate poor performance than to manage it: all forms of empirebuilding one might expect from simple public-choice models of bureaucracy. At the same time, there are few incentives for defence managers to take risks with cost-reducing innovation and process improvement, and they rarely do. Indeed, serious defence reform usually only occurs after a government circumvents or at least tries to ameliorate principal-agent problems by soliciting third-party advice from external reviewers or consultants; that is, by trying to reduce the information asymmetry between itself as the principal and Defence as its agent.

The standard remedy for public-sector inefficiency has been to outsource activities with the goal of achieving private-sector productivity levels through competition and high-powered incentives for cost-minimisation. Of course, success then depends (among other things) on the acumen with which contracts are struck and managed, all the more so as the high-powered incentives create risks that added profits will be sought from inflating charges to taxpayers. Ultimately, outsourcing exchanges one set of problems for another, and the problems associated with contracting for the supply and support of defence materiel can be acute. As we note below, this has most obviously been the case with materiel which is specific to the defence context (indeed, possibly specific to the Australian forces), involves high sunk costs and long delivery schedules, has performance characteristics difficult to fully specify in advance and is supplied under conditions that are remote from perfect or even effective competition.

Finally, the structure of a defence organization is important. First, because different distributions of activities can be more or less efficient depending on the extent of duplication, internal transaction costs, administrative overheads and economies of scale. Second, because structure determines the extent and nature of internal principal-agent relations within the organization.

A central issue in this respect is the balance between eliminating duplication, usually with a view to achieving economies of scale, and securing economies of scope. ${ }^{3}$ Consolidation almost always increases the separation between those nominally accountable for delivering military outputs and those responsible for pooled supporting activities such as materiel sustainment, corporate

3 Economies of scope are the gains that come from undertaking activities jointly. 
services and garrison support. In turn, that separation reduces the alignment of incentives between the providers of those services and the providers of military outputs, thereby creating difficult contracting issues.

\section{The Long Search for Efficiency}

The Australian defence organisation (Defence) has been shaped by the efforts of successive governments to improve efficiency, beginning with the amalgamation of the Army, Navy and Air Force departments into a unitary department in the early 1970s under the Tange reforms (Tange 1973). While not explicitly aimed at improving efficiency, the amalgamation sought to 'strengthen central control of military operations and of resources allocated to defence activities' (Tange 1973: para 20). And in tacit recognition of the principal-agent problem, the first aim of the reforms was 'an organisation that will place control in the hands of responsible government' (para 24). This was by contrast to a structure that was viewed as primarily driven by the interests of the individual services, with insufficient coordination between them and little effective oversight of overall effectiveness.

The Tange reforms created a federated structure with centralised policy development and financial management. As a result, the services retained control over most of their day-to-day activities but lost formal responsibility for force development (the evolution of the force structure through the acquisition and disposal of military equipment). In principle at least, the size and shape of the defence force would henceforth be planned centrally rather than emerge from the separate plans of the navy, army and air force.

Subsequent reviews and reforms in the 1970s and 1980s tinkered with the model (Andrew 2001), including hiving off materiel production to form the Department of Defence Support before reattaching it to Defence proper in 1984. But it was not until close to the end of the 1980s that the search for efficiency gained real momentum. Figure 1 shows the key milestones thereafter. 
Figure 1: Defence Reform 1985 to 2010

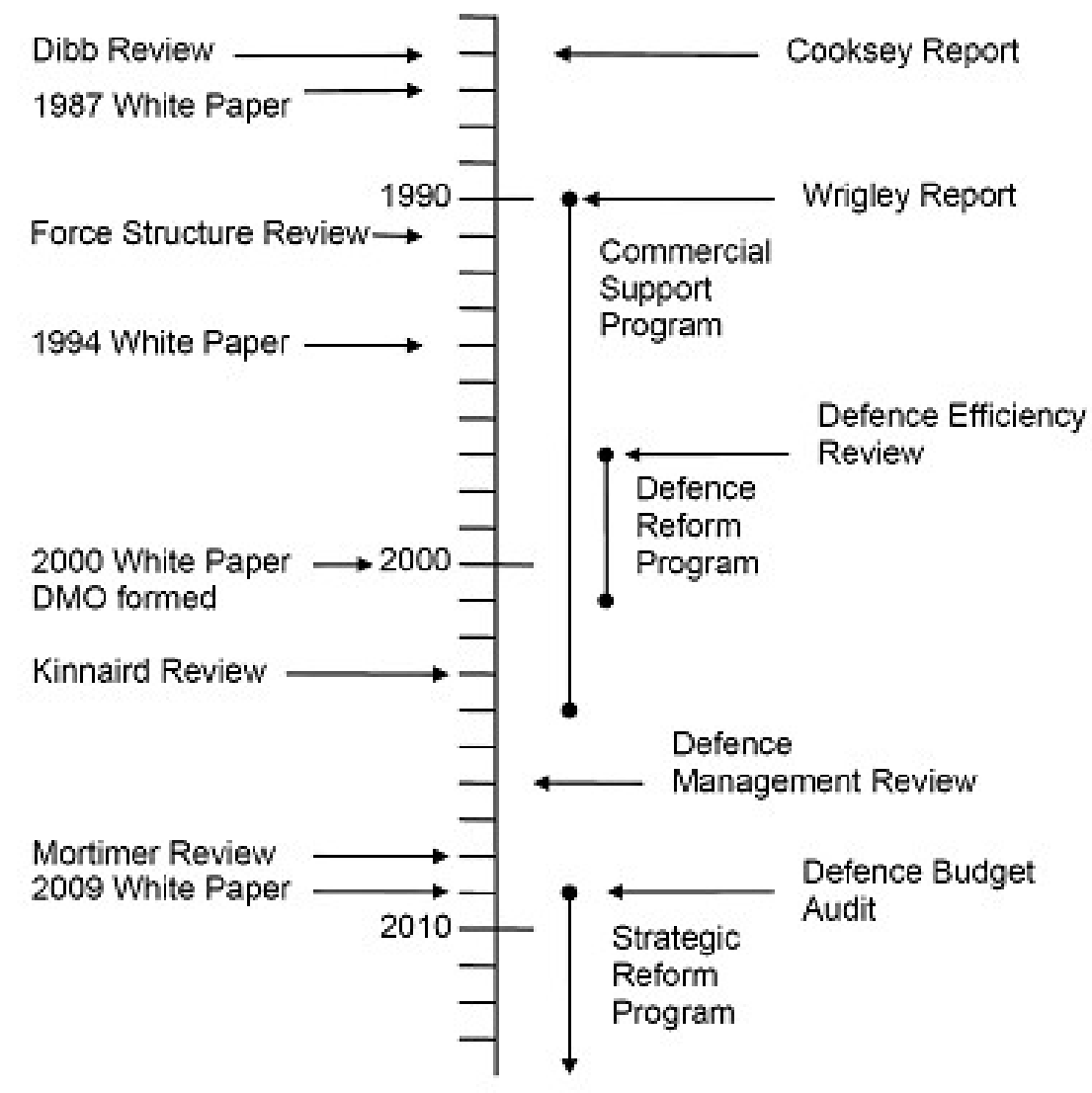

Source: Defence Annual Reports 1984 to 2010.

First came the 1986 Cooksey Report (Cooksey 1986), which recommended the corporatisation and subsequent privatisation of the government's (notoriously inefficient) shipyards, aircraft factories and munitions plants. Through the 1990s, this saw around 20,000 workers taken off the public payroll. Next came the 1990 Wrigley Report (Wrigley 1990), which led to the Commercial Support Program $^{4}$ leading to the market testing of more than 16000 uniformed and civilian positions, of which around 66 per cent were ultimately transferred to the private sector. ${ }^{5}$ Activities transferred ranged from equipment maintenance to catering and cleaning.

But the most far-reaching reforms of Defence as such followed the 1997 Defence Efficiency Review (Department of Defence 1997) which saw the accelerated out-sourcing of support activities and the sale of surplus real estate under

4 Australian National Audit Office (1998).

5 Department of Defence (2004). 
the subsequent Defence Reform Program (DRP). More critically, Defence was restructured to remove duplication between the three Services and create a central delivery model for a range of support activities.

For a variety of reasons that need not concern us, it is questionable whether the DRP achieved the savings that had been promised. Of the $\$ 941$ million in planned savings, only $\$ 644$ million was ever reported as achieved, and most of this was used to reverse planned military personnel reductions for no visible increase in military capability. ${ }^{6}$ Nonetheless, the DRP significantly changed the way Defence operates. Most directly, by moving to a shared services model it stripped the services of control of many of the resources necessary to deliver their capability outputs, including garrison support, information technology, personnel services, and equipment repair and maintenance. The result was an internal command economy run from the centre. This arrangement replaced vertical principal-agent relationships within the services with tripartite arrangements between central planners and suppliers and consumers across the breadth of the organisation.

Less visible was the amalgamation of previously duplicate civilian and military policy development functions such as personnel policy and force development. While the removal of duplication reduced overheads temporarily, it removed the civilian oversight that was intrinsic to the arrangements established by the Tange reforms a quarter-century earlier. The unstated purpose of civilian oversight was to constrain the risks inherent in having the military setting its own agenda. ${ }^{7}$ This found its clearest expression in 1986, when senior bureaucrat Paul Dibb was asked to review the structure of the defence force (Dibb 1986). Moreover, prior to 1997 it was standard practice for civilian analysts to scrutinise and contest force-development proposals from the military. The DRP saw responsibility for advising government on force-development proposals pass from senior civilians to military officers (Davies 2010).

Subsequent reforms focused on equipment acquisition and support. First, a review by accounting firm KPMG led to the amalgamation of the materiel sustainment and acquisition functions to create the Defence Materiel Organisation in June 2000. Subsequently, the 2003 Kinnaird (Department of Defence 2003) and 2008 Mortimer (Mortimer 2008) reviews, initiated in the wake of successive defence procurement bungles, led to further reforms to the planning and delivery of materiel acquisition and sustainment, including the re-establishment of DMO as a quasi-independent agency. ${ }^{8}$

6 Australian National Audit Office (2001) and Thomson (2003).

7 A less sympathetic interpretation of the influence of civilians before 1997 can be found in; James (2000).

8 The Defence Materiel Organisation is a prescribed agency under the 1997 Financial Management and Accountability Act. In other regards, its CEO reports to the Secretary and Chief of the Defence Force under the 1903 Defence Act and 1999 Public Service Act. 
An external Defence Management Review occurred in 2007 (Department of Defence 2007), but despite broad terms of reference it did little more than increase the number of senior executives and officers. Between 2000 and 2008, there were a series of 'savings programs' as part of the annual budget process. ${ }^{9}$ These various programs are claimed to have delivered around $\$ 600$ million in recurrent annual savings - though this is highly implausible given the absence of substantive changes to business practice and continued strong growth in the budget and workforce. ${ }^{10}$

In effect, not since Vietnam has Australian defence funding increased as quickly as it has over the past decade: an effective annual rate of 4.4 per cent above inflation exclusive of operational supplementation (see Figure 1). As the Defence Management Review wryly observed in 2007, the 'current comparative wealth of Defence means that there is now less concern about efficiency than in the past'. Consistent with this, administrative overheads grew rapidly during that time, as measured by the proliferation of senior executives, middle managers and non-combatant civilians (see Table 1). The rates of growth are reminiscent of the classic 1950s satirical work Parkinson's Law: The Pursuit of Progress (Parkinson 1958), which purported to show that the number of admiralty officials was inversely proportional to the number of capital ships in the Royal Navy.

Table 1: Workforce Growth 2000-200911

\begin{tabular}{llll}
\hline & $\mathbf{2 0 0 0 / 0 1}$ & $\mathbf{2 0 0 9 / 1 0}$ & Growth \\
\hline $\begin{array}{l}\text { Top executives } \\
\text { Civilian }\end{array}$ & 11 & 16 & $45 \%$ \\
Military & 5 & 7 & $40 \%$ \\
Senior executives & & & \\
Civilian & 103 & 164 & $59 \%$ \\
Military & 120 & 173 & $44 \%$ \\
Middle managers & 3317 & 5534 & $67 \%$ \\
Civilian & 1415 & 1937 & $37 \%$ \\
Military & & & \\
Other staff & 12872 & 14360 & $12 \%$ \\
Civilian & 48820 & 55587 & $14 \%$ \\
Military & & & \\
\hline
\end{tabular}

9 Thomson 2008: Section 3.

10 Ibid.

11 Top executives are three-star military officers and above, and civilian deputy-secretary and equivalent and above. Senior executives are star-ranked military officers and civilian Senior Executive Service employees. Middle managers are military colonel and lieutenant-colonel equivalent and civilian executive level 1 and 2 employees. 
Funding has been so generous that on a number of occasions Defence has literally been unable to spend its annual budget by a substantial margin. This is indicative not just of the rapid growth in funding but also of Defence's incomplete understanding of its costs - neither of which bodes well for efficiency.

The seeming generosity of that funding notwithstanding, as the end of the last decade approached the view emerged that the government's long-term goals for the defence force could not be afforded within planned funding. Costs continued to rise rapidly and there was a growing perception that inadequate account had been taken of the cost of crewing and maintaining a wide range of new platforms scheduled to enter service.

\section{Figure 2: Baseline Defence Funding and Savings 2000-18}

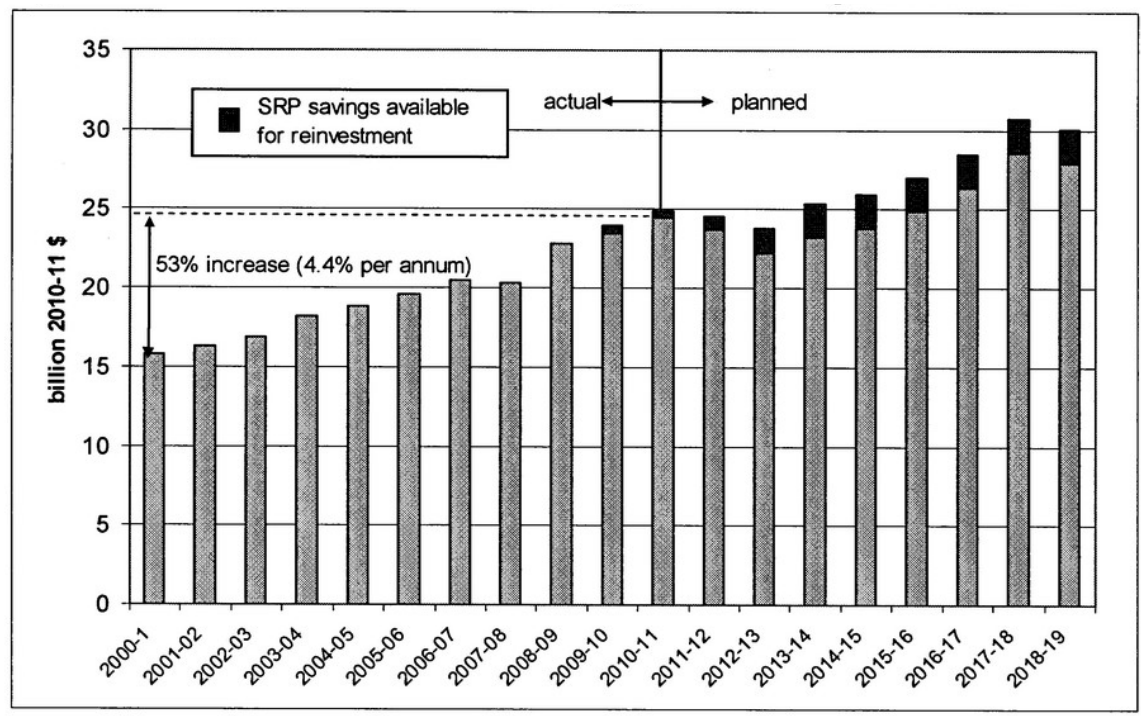

Note: Baseline funding excludes supplementation for overseas deployments.

Reflecting those concerns, in 2008 the government, as it began work on a new Defence White Paper, commissioned an independent Defence Budget Audit. The audit identified between $\$ 15$ and $\$ 20.7$ billion of possible savings over the forthcoming decade (Pappas 2009). The subsequent 2009 Defence White Paper (Department of Defence 2009a) set out a 21-year plan for the defence force contingent on savings from what is called the Strategic Reform Program (SRP). ${ }^{12}$ The SRP claims to be generating gross savings of $\$ 20.6$ billion in the decade to 2018-19, all of which are to be retained by Defence to help cover new spending initiatives arising from the White Paper, including both new capability and

12 Department of Defence (2009b); Department of Defence (2010b). 
remediation of corporate infrastructure. Since no money is actually returned to the government, the 'savings' are an accounting exercise calculated relative to a business-as-usual estimate of what costs would have been absent reform.

Initial reports of SRP savings were encouraging. In 2009/10 gross savings of $\$ 1022$ million were claimed compared with a target of $\$ 797$ million. But in 2010/11, Defence found itself in the embarrassing position of handing back \$1.5 billion of unspent money. The most likely explanation is that Defence asked for and was given more money than it needed in the 2009 Defence White Paper at least for the near term. The government appears to agree; they responded by deferring $\$ 1.3$ billion of capital investment and reducing recurrent funding by $\$ 3.3$ billion over the next 10 years.

Given Defence's demonstrated failure to understand its near-term financial needs, the massive savings being claimed under the SRP are almost certainly exaggerated - dependent as they are on easily manipulated long-term estimates of business-as-usual costs. ${ }^{13}$ Be that as it may, for our purpose what matters is the potential for the SRP to improve Defence's efficiency rather than the quanta of savings so derived. In the next section, the efficiency of current arrangements within Defence is examined, taking account of the likely impact of planned reforms.

\section{The Current Situation}

\section{Accountability, governance and structure}

Issues of accountability and governance within Defence are inextricably entwined with its structure. Defence is made up of 14 major business units called 'groups': five which directly deliver outputs (navy, army, air force, operations and intelligence); four which materially support the delivery of those outputs (science and technology, materiel sustainment/acquisition, nonmateriel support and IT services); and five administrative groups which largely, but not exclusively, develop policy and coordinate activity. ${ }^{14}$

Were they fully efficient, the supporting groups would provide the mix of inputs that best meets the needs of the output groups at minimum cost. This demands that the mix of potentially substitutable inputs minimises the cost of the final output. It falls to the central planners in the administrative groups to orchestrate this by allocating resources and setting performance targets for both the supporting and output groups.

13 Thomson 2011: Chapter 4.

14 Ibid: Chapters 1 and 2. 
Four problems arise. First, Defence's central planners lack reliable information about costs and performance across the organisation. Second, even if the central planners were omniscient, they lack the economic and commercial expertise to even begin to ensure efficiency (as evidenced by the 2008 Budget Audit). Third, there is no single central planner in defence. Indeed, there is no single central plan beyond the financial budget. Instead, a series of loosely connected plans for personnel, preparedness, finance and investment are developed in parallel and cobbled together to form the so-called Defence Planning Guidance document. Moreover, there is no single headquarters or chief administrative officer. Instead, the five administrative groups exist in parallel to each other and those they seek to administer, with no coordinating function below the departmental Secretary and military Chief (known collectively as the 'diarchy'). Governance is achieved through an unwieldy Defence Committee with 16 members plus a Chiefs of Service Committee of six members for exclusively military matters (a questionable concept). Below these two committees there are hundreds of subordinate committees, working groups and forums. As a command economy run as a federation, it is inevitable that extensive resources are devoted to intra-departmental coordination, in a process characterized by widespread bargaining inefficiencies.

Fourth, Defence lacks the sanctions and incentives used by the private sector to ensure compliance and drive performance. Although this is mitigated somewhat in the military through centralized promotion and career management, incentive problems pervade Defence's civilian workforce. More generally, public-service employment practices limit Defence's ability to attract high-performing individuals from the private sector or remove underperforming ones from within its ranks. Related to this, it is not uncommon to find relatively junior public servants and military officers, with little or no commercial experience, supervising projects worth many millions of dollars.

To make matters worse, the government is decidedly poorly placed to monitor Defence's day-to-day performance. The spectacular - and for the government entirely unexpected - failure of the entire amphibious lift fleet in early $2011^{15}$ is testament to the difficulty of monitoring Defence's performance. The subsequent external report (Rizzo 2011) into the collapse of the amphibious capability contains clear evidence of not only inadequate communication but of profound organisational dysfunction within Defence consistent with the discussion above.

15 The failure of the amphibious capability is recounted in a speech by Defence Minister Stephen Smith on 15 February 2011. More revealing still is the explanation from Defence released the same day by the Minister, available at www.defence.gov.au/media/docs/causalFactors.pdf (accessed 9 November 2011). 
The SRP includes a number of initiatives to improve accountability and governance within Defence. Management information systems are to be improved, measures of effectiveness are to be developed, costs are to be made more transparent, roles and responsibilities are to be clarified, internal servicelevel agreements are to negotiated and documented, and committees are to be made more effective. A subsequent external review of accountability (Black 2011) in Defence reinforced and expanded the reform agenda, including by recommending a reduction in the number of committees and the introduction of a corporate plan.

As far as they go, the raft of planned reforms is entirely sensible. But most of the initiatives have been promised repeatedly over the past decade yet never delivered. Unless the government drives the changes, there is every chance that things will remain as they are. Moreover, most of the initiatives are about making existing arrangements work better without addressing the underlying dysfunctions.

Critically, the proposed reforms do too little to ameliorate the internal principalagent problem between the support and output groups. The 2008 budget audit recommended moving to an 'output-focused' budget framework that would give greater control of resources to the output groups ${ }^{16}$ (effectively removing the central planner from the triangle). That would have raised difficult implementation issues but would at least have forced Defence to tackle many of the issues raised above. It now appears that something less substantial is envisaged.

Finally, and most importantly, the present package of reforms does nothing to address the principal-agent problem between the government and Defence the problem which creates the environment that allows all the other maladies to persist.

\section{Productivity: ensuring the efficient use of resources}

Quite apart from the structural impediments to efficiency built into Defence's business model, there is the question of how efficiently individual activities are performed within Defence and on Defence's behalf by the private sector.

It is beyond the scope of this short paper to canvass the efficiency of the extensive range of activities that Defence undertakes - the 2008 Budget Audit devoted 141 pages to the question and was not comprehensive. Briefly, the SRP plans to boost efficiency by imposing greater cost-consciousness, introducing more commercially astute practices, and making more-efficient use of labour. All

16 Pappas (2009). 
of this is sensible and to be commended. That said, the recent announcement of the creation of two new associate secretary positions erodes hope that the disproportionate growth in executives will ever be stemmed.

What is worrying is that there is no mechanism to secure ongoing improvements in production efficiency beyond the present round of externally conceived initiatives. In the absence of more effective governance and accountability, there is a risk that Defence will gradually return to the comfort of doing less with more.

In any case, there are the practical limits of what can be achieved. While worthwhile savings can be anticipated from the SRP, they are of secondary importance to the prime determinants of defence costs: namely, the range and scale of capabilities possessed. In practice, the bulk of the costs associated with a military capability are fixed by the decision to own and operate the capability. The dominance of fixed costs elevates the importance of achieving efficiency in the product mix in defence planning.

\section{Capability planning: achieving efficiency in the product mix}

Within Defence, literally hundreds of people work on developing strategic policy and translating it into concrete plans for the development of the defence force (Department of Defence 2006; 2010a). The result is the Defence Capability Plan (Department of Defence 2011), which is a decade-long program of major acquisitions.

Were that plan efficient, it would ensure two things. First, that the 'right' defence capabilities are sought consistent with prevailing circumstances and strategy. Second, that planned defence capabilities are deliverable within available resources - financial, human and bureaucratic.

That these criteria are closely related is obvious. Thus, in a perfect world, budgets would be allocated between the various objects of public expenditure such that the marginal dollar of expenditure yielded the same benefit across all programs, projects and project elements. In practice, however, the allocation of public expenditure is a sequential process, and it is the task of each budget holder to make efficient use of a predetermined budget by seeking to secure the most output - in our case the most defence - for the outlay available.

At least, that is how such a planner might act were the resource constraint 'hard'; that is, not vulnerable to renegotiation in response to decisions that can be taken by defence itself. In contrast, with a soft budget constraint, the incentive, rather than being to secure the most defence from the given budget, 
will be to try to expand the budget itself, including by capability commitments that can force the hands of future governments as and when the money runs out. Those capability commitments may bear little or no relation to opportunity costs as defined by the initial resource constraint.

Past experience is consistent with the foregoing analysis. Throughout almost all of the preceding two decades, it was clear that the government's plans for defence were unaffordable, in the sense of being inconsistent with likely future budgets, and those rare occasions where things appeared otherwise (such as immediately after the 2000 White Paper) proved to be delusions. Similar problems have long arisen in both the United Kingdom (Gray 2009) and the United States. ${ }^{17}$ Although optimism bias has probably played an important role (Flyvbjerb 2006), it is equally likely that Defence carelessly, or perhaps even deliberately, committed the government to higher than acknowledged costs — as might be expected from an agent operating in an environment with unenforceable budget constraints and where spending targets are subject to renegotiation and the political costs of cancelling programs is high once they have been announced.

The 2009 Defence White Paper introduced a 'capped budget' funding arrangement whereby 'shortfalls against the White Paper funding plan will be offset by Defence' - presumably to avoid the pitfalls of a soft resource constraint. But although this may encourage greater rigour on the part of defence planners in the near term, it is unlikely to have anything like the effect of an actual hard budget constraint in the long run. Not only is the capped budget rule weakened by the periodic reviews of funding and plans, but the risks associated with poor planning are inevitably borne by the government. Put simply, as both sole customer and shareholder, the government cannot allow Defence to fail if it runs out of money. The capped budget is ultimately unenforceable and known to be.

It remains to be seen if the plans set out in the 2009 White Paper are affordable. On the basis of historical trends in the cost of acquiring and operating military equipment, in appears as though long-term funding was inadequate to start with (Lynn and Davies 2009). Conversely, the recent substantial hand-back of funds demonstrates that Defence has more than enough money for the moment at least. The situation is further complicated by Defence's acute inability to progress acquisitions according to plan - irrespective of the availability of funds. ${ }^{18}$ Only time will tell whether current plans are affordable or not, though we have good grounds to suspect they are not.

More difficult to assess, and even more critical, is whether plans maximise defence output for the available budget. As matters stand, these plans have

17 U.S. Government Accountability Office (2010).

18 Thomson 2011: Chapter 3. 
elicited at least as much criticism as support. ${ }^{19}$ And while critics rarely agree on what the alternative should be, many cite logical disconnects in the official explanations given for the planned force. The suspicion is that Defence's labyrinthine planning processes result in little more than the three services colluding to divide up available resources in order to replace existing assets and maintain their respective shares of the total resource pool. That suspicion is consistent with Australian experience over the years. ${ }^{20}$

Regrettably, there is little evidence that governments bother to grapple with the issues themselves, content instead to leave force structure planning to Defence. It is noteworthy that Defence's manual for capability development assigns the government the surely subordinate role of 'endorsing' Defence's plans (Department of Defence 2006). Moreover, there is no sign that the central agencies of Treasury, Finance, and Prime Minister and Cabinet have any influence beyond setting limits on aggregate defence spending. This at least partly reflects an underlying information asymmetry that gives Defence almost unchallenged influence over multi-billion dollar procurement decisions, with all the dangers that entails.

There is, however, some prospect for improvement. As a consequence of the recent review of accountability in defence, the government has decided to reinstitute civilian scrutiny of capability planning within Defence (Smith 2011). While this cannot be a panacea, if properly implemented it will inject muchneeded objectivity into a process that has tended to produce plans that are of questionable strategic merit, exceed available budgets and cannot be delivered in a timely way.

\section{Capital procurement}

The acquisition of military equipment is costly and risky. ${ }^{21}$ At present, Australia spends more than $\$ 5$ billion a year on around 190 major projects ranging from naval destroyers to fighter aircraft. Regrettably, defence projects frequency encounter delays and cost increases and, on occasion, fail to deliver the capability sought. ${ }^{22}$

\footnotetext{
19 A variety of perspectives on the 2009 Defence white paper can be found in Security Challenges Vol. 5, No. 2 (Winter 2009). For a critical analysis, see Davies (2010). For a broadly supportive view, see Sheridan (2009). See also the speeches by Hugh White and Paul Dibb at the National Press Club, Canberra, on 24 June 2009.

20 A brief analysis of how institutional inertia has previously prevented the alignment of capability and strategy in Australia can be found in Thomson (2007).

21 Ergas (2003; 2007), and Thomson (2008) Section 7

22 Cost increases usually arise before a project is put to contract; while schedule delays accumulate continuously through the life of a project from conception to delivery; see Thomson (2008), Section 7.
} 
Government concerns over these problems led to the Kinnaird and Mortimer reviews of defence procurement. At the risk of oversimplification, the reforms fall into two categories: (1) the operation of Defence's acquisition and sustainment agency, the Defence Materiel Organisation (DMO); and (2) the processes for project development and approval.

Broadly speaking, the reforms to DMO seek a more professional and commercially adept procurement agency. As far as they go, the reforms are sensible and worthwhile. The critical question is how effective they can be so long as DMO remains constrained by Public Service practice and dependent on military officers (whose primary expertise lies elsewhere) in project manager roles. The successful introduction of more sophisticated contracting, for example, arguably demands greater private-sector experience. Both the Kinnaird and Mortimer reviews recommended hiving DMO off as a separate entity from Defence to give it greater independence and freedom on personnel matters. But the difficulties of making DMO an independent agency are several and serious, and the recommendations were rejected. While this was probably the right decision, the downside is that DMO still lacks the flexibility it needs to manage its workforce effectively.

As a result of the Kinnaird review, major defence projects are considered at least twice by the government prior to approval. Previously, projects were often approved in batches and considered only once. So far, the new process has been accompanied by very substantial delays. Moreover, it is doubtful that Ministers are well placed to deliberate on the commercial and technical details of defence acquisitions anyway, especially with the government's central agencies poorly equipped to provide independent advice on Defence proposals. However, as already mentioned, the reintroduction of internal civilian scrutiny of capability planning has the potential to improve decision making - though perhaps at the cost of still further delays.

\section{Four Reforms}

In the current fiscal environment, there is little doubt that the government wants to trim as much fat from the defence budget as it can. The cuts imposed earlier this year are a good start; austerity and expenditure constraints are blunt but effective tools. But more can be done, especially in the so-far sacrosanct Defence workforce. The potential for further reductions should then be explored as a priority, with a focus on trimming the bloated managerial overhead. In terms of the operational military workforce, the demarcation between the Reserve and Regular force should be revisited, along with the potential for greater contractor support to operations. 
In the longer term, sustaining efficiency in Defence will demand processes, incentives and administrative structures that orient production to efficient solutions. The following four recommendations focus on the key opportunities to improve efficiency in Defence.

\section{Embrace output-focused budgeting}

As a first step, output-focused budgeting should be fully embraced. Unless the individual services control the inputs to their activities, they cannot be accountable for the quality or cost-effectiveness of what they deliver. At very least, budgeting and management information systems need to allow the military to understand the cost of inputs and alter the mix accordingly.

In addition, Defence's long-standing policy of centralising support services such as garrison support and materiel sustainment should be searchingly reviewed. Where pooled service delivery is not justified by substantial and genuine economies of scale or reduced overheads, the activity should be returned to the individual services: Army, Navy or Air Force. In some cases it may be more efficient to consolidate command and support administration locally than to aggregate administration of support across disparate geographic locations.

An output-focused business model as outlined would entail a high degree of autonomy for those responsible for delivering the capability outputs. No longer would the military be passive consumers of 'free' goods in a command economy. At the same time, central control would need to be strengthened through a regime of financial and non-financial performance measurement to allow productivity and efficiency to be monitored and reported.

Consistent with the proposed output-focused business model, Defence's present 'federated' approach to governance should be replaced by a more disciplined corporate model build around a designated headquarters. The current unwieldy Defence Committee should be replaced by a much smaller board that includes the Service Chiefs and a limited number of key people.

Finally, with an effective regime of performance measurement in place, private sector- style rewards and sanctions could be used to drive individual performance at senior levels. Apart from better aligning individual and corporate goals, such an approach would better enable Defence to compete for specialist talent in the broader labour market. Over time this would allow the development of a leaner and flatter workforce. 


\section{Increase transparency and external scrutiny}

The surest way to address the principal-agent problem between Defence and the government/taxpayer is to increase the transparency and external scrutiny of Defence. Australia is fortunate to have a number of think tanks and academic institutions working on defence matters - not to mention an active media - but their efforts are severely hampered by small scale and by secrecy surrounding almost all aspects of Defence. ${ }^{23}$ Notwithstanding recent improvements to freedom-of-information access, the government withholds much more information about Defence than can be plausibly justified on the basis of national security or commercial confidence - a case in point is the heavily redacted 2010 incoming government brief. ${ }^{24}$ By withholding all but the most anodyne details of Defence's performance, the government denies itself (and taxpayers) the benefit of third-party scrutiny and informed debate.

The paucity of information also compromises parliamentary examination of Defence: members and senators simply don't know what to ask. Apart from boosting transparency, the existing Parliamentary Library and proposed Parliamentary Budget Office should be properly equipped to analyse defence issues. The goal should be to replicate a capability akin to that held by the Congressional Research Service, Congressional Budget Office and Government Accountability Office in the United States.

Proper disclosure of Defence's performance is unlikely to occur without external involvement. Fortunately, the Australian National Audit Office (ANAO) is well placed to play a role. Since 2008 the ANAO has reported annually on the performance of the 20 largest Defence projects. ${ }^{25}$ The obvious extension would be to have the ANAO report annually on the cost and performance of major inservice defence capabilities.

\section{Get the force structure right}

No matter how efficiently defence outputs are produced, the effort is ultimately futile if the resulting force structure is not suited to Australia's needs. For this reason, the government should take a more direct interest in defence planning than it does at present - especially given the risks of moral hazard inherent in allowing the military to self-direct. It is difficult to be optimistic, however. The

\footnotetext{
23 In recent years the level of detail provided on financial and non-financial performance has declined significantly from what was an already low base. To make matters worse, frequent changes to the structure of Defence's output structure make it impossible to construct financial time-series at other than the most aggregated level.

24 Department of Defence (2010c).

25 Australian National Audit Office (2010).
} 
low political priority accorded defence policy is reflected in the revolving-door appointment of defence ministers that has seen seven defence ministers in a period covered by two treasurers.

In addition to taking responsibility for the overall size and shape of the defence force, the government needs to do a better job of directing Defence's multimillion dollar acquisition program. Many of the gaps in today's force structure are the result of failed, faltering or seriously delayed defence projects. At the risk of complicating an already labyrinthine process, the government could seek independent external advice prior to the approval of key projects.

\section{Appoint a Defence chief economist}

Defence employs more than two thousand scientists, yet there are no designated positions for economists apart from those working on foreign intelligence. So that while almost any significant technological issue is subjected to detailed scientific analysis, almost 2 per cent of the nation's income is disbursed with scant use of microeconomic analysis. Instead, resources are allocated within Defence by military personnel, generalist public servants and a handful of accountants. The result is a primary emphasis on accounting standards and limited regard for efficiency.

Economic analysis is relevant to resource allocation at every level of Defence. At the strategic level, the techniques of cost-benefit analysis and program planning and budgeting have much to offer. At the operational level, economics is relevant to everything from commercial contracting to supply-chain management.

One way to introduce the requisite expertise would be to appoint a Chief Defence Economist with broad responsibility for monitoring, benchmarking and advising on Defence's efficiency. This would hardly solve the problems discussed above, but it would at least allow those grappling with them to benefit from the insights economic analysis can provide.

\section{Postscript}

It is not known whether the army still uses ball-peen hammers to replace watch batteries. We can only hope that the confusion between panel beating and horology has been resolved. But you would not want to bet on it. The Royal Australian Navy is presently replacing its fleet of 16 Seahawk helicopters at a cost of several billion dollars because the aircraft have become difficult to maintain - despite the aircraft having only flown half their designed hours. 
Such inefficiency is truly the enemy within; it would be a pity if the Australian defence establishment, which has so often proven its value in the field, could not do better against that adversary.

\section{References}

Andrew, E. 2001, The Department of Defence, The Australian Centenary History of Defence, Vol. V, Oxford University Press, Oxford.

Australian National Audit Office 1998, Commercial Support Program, Audit Report No.2 1998-99, Canberra.

2001, Defence Reform Program — Management and Outcomes, Audit Report No.16 2001-02, Canberra.

2010, 2009-10 Major Projects Report, Audit Report No.17 2010-11, Canberra.

Black, R. 2011, Review of the Defence Accountability Framework, Department of Defence, available at: http://www.defence.gov.au/oscdf/BlackReview/black_ review.pdf.

Builder, C. 1989, The Mask of Wars: American Military Styles in Strategy and Analysis, RAND Corporation Research Study, Baltimore MD: Johns Hopkins University Press.

Cooksey, R. 1986, Review of Australia's Defence Exports and Defence Industry, Australian Government Publishing Service, Canberra.

Davies, A. 2010, Let's test that idea - contestability of advice in the Department of Defence, Australian Strategic Policy Institute, Canberra.

Davies, A. et al. 2010, Australian Defence Policy Assessment 2010, Australian Strategic Policy Institute, Canberra.

Department of Defence 1997, Future Directions for the Management of Australia's Defence, Report of the Defence Efficiency Review, Canberra.

2003, Report of the Defence Procurement Review, Canberra.

2004, Defence Annual Report 2003-04, Table 6.2, p.311.

2006, Defence Capability Development Manual 2006, Canberra.

2007, Report of the Defence Management Review, Canberra. 
2009a, Defending Australian in the Asia-Pacific Century: Force 2030, Defence White Paper, Canberra.

2009b, The Strategic Reform Program - Delivering Force 2030, Canberra, at: www.defence.gov.au/srp/ (accessed 9 November 2011).

2010a, Defence Strategy Framework 2010, Canberra.

2010b, The Strategic Reform Program - Making it Happen, Canberra, at: www.defence.gov.au/srp/ (accessed 9 November 2011).

2010c, Incoming Government Brief, Canberra.

2011, Defence Capability Plan 2011, Canberra.

Dibb, P. 1986, Review of Australia's defence capabilities, Australian Government Publishing Service, Canberra.

Ergas, H. 2003, Some Economic Aspects of the Weapons System Acquisition Process, at: http://www.aspi.org.au/dcp_review/some_economic_aspects_ of_weapons_systems_acquisition_he_aug_03.pdf (accessed 9 November 2011).

Ergas, H. 2007, 'In the Dark: Defence Spending', The Review (supplement to the Australian Financial Review), 9 February, p.1.

Flyvbjerb, B. 2006, 'From Nobel Prize to Project Management: Getting Risks Right', Project Management Journal, August.

Gray, B. 2009, Review of Acquisition for the Secretary of State for Defence, UK Ministry of Defence, London.

James, N. 2000, Reform of the Defence Management Paradigm: A Fresh View, Working Paper, Australian Defence Studies Centre, Canberra.

Lyon, R. and Davies, A. 2009, Assessing the Defence White Paper 2009, Australian Strategic Policy Institute, Canberra.

Mortimer, D. 2008, Going to the Next Level - Report of the Defence Procurement and Sustainment Review, Defence Material Organisation, Canberra.

Pappas, G. 2009, 2008 Audit of the Defence Budget, Department of Defence, Canberra.

Parkinson, C. N. 1958, Parkinson's Law: The Pursuit of Progress, John Murray, London. 
Rizzo, P. 2011, Reform of Amphibious and Afloat Support Ship Repair and Management Practices, Department of Defence, available at: http://www. defence.gov.au/oscdf/rizzo-review/.

Sheridan, G. 2009, 'A battle of words', The Australian, 2 May.

Smith, S. 2011, Improving personal and institutional accountability in Defence, media release, 9 August, Minister for Defence, at: http://www.minister. defence.gov.au/2011/08/09/improving-personal-and-institutionalaccountability-in-defence/ (accessed 9 November 2011).

Smith, S. and Clare, J. 2010, Joint Media Release, Projects of Concern - Update, Canberra, 26 November.

Tange, A. 1973 Australian Defence; Report on the Reorganisation of the Defence Group of Departments, Department of Defence, Canberra.

Thomson, M. 2003, Sinews of War; The Defence budget in 2003 and how we got there, Australian Strategic Policy Institute, Canberra.

2007, 'The Challenge of Coherence, Strategic Guidance, Capabilities and Budgets' in Huisken, R. and Thatcher M. (eds), History as Policy: Framing the debate on the future of Australia's defence policy, Australian National University Press, Canberra.

2008, The Cost of Defence 2008-09, Australian Strategic Policy Institute, Canberra.

\section{Canberra.}

2011, The Cost of Defence 2011-12, Australian Strategic Policy Institute,

U.S. Government Accountability Office 2010, Defense Acquisitions: Assessments of Selected Weapon Programs, Washington.

Weinberg, S. 'What Price Glory?' in Weinberg, S. 2009, Lake View: This World and the Universe, Cambridge MA: Harvard University Press, Chapter 12.

Wrigley, A. 1990, The Defence Force and the Community, Australian Government Publishing Service, Canberra. 